\title{
PROFIL PEMAHAMAN MAHASISWA DALAM MENYELESAIKAN SOAL-SOAL TRIGONOMETRI PADA MATA KULIAH ANALISIS VEKTOR
}

\author{
Restu Lusiana, S.Pd., M.Pd. \\ IKIP PGRI Madiun, Kota Madiun
}

\begin{abstract}
Abstrak. Menganalisis pemahaman mahasiswa dalam penelitian ini bertujuan untuk mengetahui seberapa besar mahasiswa memahami pengguanaan langkah-langkah untuk menyelesaikan soal-soal trigonometri. Subyek dalam penelitian ini adalah mahasiswa semester VI kelas H Program Studi Pendidikan Matematika IKIP PGRI Madiun yang dikategorikan menjadi tiga kategori, yaitu dua subyek dengan kategori tinggi, dua subyek dengan kategori sedang, dan dua subyek dengan kategori rendah.

Jenis penelitian yang digunakan adalah kualitatif. Teknik pengambilan subyek dilakukan dengan cara melihat nilai UTS mahasiswa semester genap tahun 2012/2013. Teknik pengumpulan data dalam penelitian ini diperoleh berdasarkan hasil tes, wawancara, dan dokumentasi. Teknik analisis data dalam penelitian ini terdiri dari reduksi data, penyajian data, dan penarikan kesimpulan serta verifikasi, serta teknik keabsahan data dalam penelitian ini dengan triangulasi data.

Kesimpulan dari hasil penelitian ini adalah (1) Mahasiswa kategori tinggi menunjukkan bahwa mahasiswa berkecenderungan memiliki pemahaman yang baik yaitu dalam mengaplikasikan langkahlangkah dengan tepat dalam menyelesaikan soal-soal trigonometri. Mahasiswa dapat memberikan penjelasan penyelesaian soal dengan benar, (2) Mahasiswa kategori sedang menunjukkan bahwa mahasiswa berkecenderungan memiliki pemahaman yang cukup baik dalam mengaplikasikan langkahlangkah untuk menyelesaikan soal-soal trigonometri. Secara umum mahasiswa dapat memberikan penjelasan penyelesaian soal dengan benar, tetapi masih belum tepat, dan (3) Mahasiswa kategori rendah menunjukkan bahwa mahasiswa berkecenderungan memiliki pemahaman yang kurang baik dalam mengaplikasikan langkah-langkah untuk menyelesaikan soal-soal trigonometri. Secara umum mahasiswa tidak dapat memberikan penjelasan dalam penyelesaian soal dengan benar.
\end{abstract}

Kata Kunci: Profil pemahaman mahasiswa, Mengaplikasikan langkah-langkah, Menyelesaikan soal-soal trigonometri.

\section{Pendahuluan}

Pendidikan merupakan faktor utama yang mempengaruhi kualitas kehidupan bangsa. Peran pendidikan sangat penting untuk menciptakan kehidupan yang cerdas, damai, terbuka dan demokratis. Dewasa ini telah terjadi perubahanperubahan yang sangat cepat di segala bidang, mengharuskan kita menyesuaikan dan mengembangkan cara-cara penyempurnaan pada semua mata pelajaran. Oleh karena itu, berbagai upaya peningkatan kualitas, proses, dan hasil pendidikan senantiasa dicari, diteliti dan diupayakan melalui kajian berbagai komponen pendidikan.

Pendidikan merupakan usaha untuk mengembangkan potensi Sumber Daya Manusia (SDM) melalui kegiatan pembelajaran. Potensi sumber daya manusia merupakan aset nasional sekaligus sebagai modal dasar pembangunan bangsa. Potensi ini dapat digali dan dikembangkan serta dipupuk secara efektif melalui strategi pembelajaran yang terarah dan terpadu, yang dikelola secara serasi dan seimbang dengan memperhatikan pengembangan potensi siswa secara utuh dan optimal. 
Karena itu, strategi pendidikan perlu secara khusus memperhatikan pengembanagn potensi peserta didik yeng memiliki kemampuan dan kecerdasan luar biasa (unggul).

Matematika merupakan ilmu dasar yang dipelajari siswa mulai sejak dini sampai tua. Penguasaan terhadap matematika sangat diperlukan untuk menghadapi kemajuan pendidikan dan teknologi. Matematika berkenaan dengan ide-ide atau konsep-konsep abstrak yang tersusun secara hirearkis dan penalaran deduktif. Selain itu, matematika adalah sarana berpikir dalam menentukan dan mengembangkan ilmu pengetahuan dan teknologi, bahkan matematika merupakan metode berpikir logis, sistematis dan konsisten. Oleh karenanya semua masalah kehidupan yang membutuhkan pemecahan secara cermat dan teliti selalu harus merujuk pada matematika. Maka proses belajar matematika akan terjadi dengan lancar bila belajar itu sendiri dilakukan secara berkelanjutan. Sehingga diperlukan kemampuan belajar matematika dari setiap siswa.

Inti dari pelajaran matematika sebenarnya hanyalah penambahan, pengurangan, perkalian dan pembagian. Jika kita bisa menguasainya dengan baik maka matematika akan terasa lebih mudah dari yang kita bayangkan. Matematika sebenarnya tidak memerlukan hafalan rumus, tapi yang dibutuhkan dalam matematika sebenarnya adalah pemahaman. Kadang saat siswa mengerjakan soal, dia hanya tahu atau hafal rumusnya tanpa dia pahami cara penggunaanya, sehingga siswa kadang bingung untuk menyelesaikan soal-soal tersebut. Jika siswa dari awal sudah terbiasa menghafal tanpa memahami apa yang dia kerjakan, maka siswa akan selalu merasa kesulitan dalam belajarnya.
Pemahaman matematika itu sendiri tergantung dengan pribadi siswa, banyak cara yang dapat dilakukan untuk menanamkan rasa paham pada diri siswa, karena setiap siswa pola pikir dan kemampuanya sangat berbeda. Sehingga dalam penyelesaian suatu masalah siswa hanya mengerjakan sesuai dengan apa yang diajarkan gurunya tanpa memahaminya.

Siswa kadang dituntut untuk mengerjakan soal sesuai dengan yang diajarkan oleh gurunya. Padahal sebenarnya guru hanya sebagai fasilitas siswa dalam mengkonstruksi atau membangun pola pikirnya, sehingga siswa mampu menemukan konsep penyelesaian dari suatu permasalahan. Pada saat siswa belajar membangun pola pikirnya siswa akan menemukan pemahamannya sendiri, pemahaman itulah yang harusnya dikembangkan oleh siswa dengan mengacu pada perkembangan ilmu matematika.

Trigonometri adalah salah satu materi yang ada di dalam mata kuliah Analisi Vektor. Materi ini berhubungan dengan sudut-sudut yang meliputi sinus, cosinus, tangen, secan, cosecan, dan cotangen. Pemahaman awal dalam menyelesaikan masalah trigonometri harus diperhatikan, karena jika sudah salah pemahaman dari awal, selanjutnya pasti merasa kesulitan.

Berdasarkan pengamatan dan hasil wawancara peneliti dengan mahasiswa IKIP PGRI Madiun semester VI kelas H, sebagian besar mahasiswa kurang paham dalam menggunakan rumus untuk memecahkan masalah matematika, khususnya materi trigonometri pada mata kuliah Analisis Vektor. Hal itu terlihat dari nilai UAS mata kuliah Analisis Vektor tahun 2013 yang sebagian besar masih di bawah rata-rata kelas.

Profil pemahaman adalah gambaran tentang pemahaman seseorang dalam 
menguasai materi dan menerapkannya dalam menyelesaikan masalah suatu masalah. Penanaman pemahaman tentang suatu materi pada seseorang sejak awal sangat dianjurkan untuk mempermudah mempelajari dan memahami materi-materi selanjutnya, serta untuk mempermudah pemecahan masalah yang berkaitan dengan materi yang dipahami.

Menurut Polya (dalam Suherman, dkk, 2003:91), solusi pemecahan masalah memuat empat langkah penyelesaian, yaitu langkah pertama adalah memahami masalah. Tanpa adanya pemahaman terhadap masalah yang diberikan, siswa tidak mungkin mampu menyelesaikan masalah tersebut dengan benar. Setelah siswa dapat memahami masalah dengan benar, selanjutnya mereka harus mampu menyusun rencana penyelesaian masalah. Kemampuan melakukan langkah kedua ini sangat tergantung pada pengalaman siswa dalam menyelesaikan masalah. Jika rencana penyelesaian masalah telah dibuat, baik secara tertulis atau tidak, selanjutnya dilakukan penyelesaian masalah sesuai dengan rencana yang dianggap paling tepat. Adapun langkah terakhir dari proses penyelesaian masalah menurut Polya adalah melakukan pengecekan atas apa yang telah dilakukan mulai dari langkah pertama sampai langkah terakhir. Kelebihan sistem pemecahan masalah berdasarkan langkah yang dikemukakan Polya adalah karena langkah Polya menyediakan kerangka kerja yang tersusun rapi untuk menyelesaikan masalah yang kompleks sehingga dapat membantu seseorang dalam memecahkan masalah.

Dari uraian di atas dapat disimpulkan bahwa pemahaman siswa dalam menerapkan rumus untuk menyelesaikan suatu masalah masih sangat kurang. Oleh karena itu peneliti menganggap perlu diadakan penelitian dengan tujuan untuk mengetahui profil pemahaman siswa dalam menerapkan rumus untuk menyelesaikan suatu masalah.

Tujuan penelitian mengungkapkan sasaran yang ingin dicapai yang mengacu pada isi dan rumusan masalah yang telah di rumuskan. Oleh karena itu sesuai dengan permasalahan, maka tujuan penelitian ini adalah untuk mengetahui profil pemahaman mahasiswa dalam mengaplikasikan langkah-langkah atau menerapkan rumus untuk menyelesaikan soal-soal trigonometri pada mata kuliah Analisis Vektor.

\section{Metode Penelitian}

Penelitian ini menggunakan pendekatan kualitatif. karena berlandaskan filsafat postpositivisme, digunakan untuk meneliti kondisi obyek alamiah, dimana peneliti adalah sebagai instrumen kunci, pengambilan sampel data dilakukan secara purposive dan snowball, teknik pengumpulan dengan trianggulasi (gabungan), analisis data bersifat induktif atau kualitatif dan hasil penelitian kualitatif lebih menekan makna dari pada generalisasi (Sugiyono, 2010: 15).

Dalam penelitian ini, peneliti berusaha untuk menganalisis pemahaman mahasiswa dalam menerapka rumus untuk memecahkan masalah matematika. Selain untuk memecahkan masalah matematika, peneliti juga berusaha untuk memaparkan pemahaman siswa untuk memecahkan masalah tersebut, hal ini berdasarkan rumusan masalah dalam penelitian ini.

Penelitian kualitatif bersifat induktif yaitu peneliti membiarkan permasalahanpermasalahan muncul dari data atau dibiarkan terbuka untuk interpretasi. Data dihimpun dengan pengamatan yang seksama, mencakup deskripsi dalam konteks yang mendetail disertai catatancatatan hasil wawancara yang mendalam, 
serta hasil analisis dokumen dan catatancatatan.

Penelitian ini merupakan penelitian deskriptif-kualitatif, karena dalam data penelitian ini tanpa menggunakan perhitungan angka, melainkan dengan kata-kata dan lebih menekan pada makna. Dalam penelitian ini peneliti adalah instrumen kunci dan analisis data dilakukan secara induktif.

Sesuai dengan rumusan masalah yang telah dipaparkan di atas, peneliti memecahkan masalah matematika dengan pokok bahasan penerapan rumus dalam menyelesaikan soal-soal terigonometri dalam mata kuliah Analisis Vektor. Penelitian ini merupakan jenis penelitian tindakan partisipan. Alasan peneliti mengambil jenis penelitian ini karena peneliti bertindak langsung dalam penelitian, mulai dari awal sampai akhir penelitian.

\section{Teknik Pengumpulan Data}

Teknik pengumpulan data merupakan langkah yang paling strategis dalam penelitian, karena tujuan utama dari penelitian adalah mendapatkan data. Tanpa mengetahui teknik pengumpulan data, maka peneliti tidak akan mendapatkan data yang memenuhi standar data yang ditetapkan.

Sugiyono (2010:193) menyatakan data dapat dilakukan dalam berbagai setting, berbagai sumber, dan berbagai cara. Dalam penelitian ini, teknik pengambilan data yang diambil oleh penulis adalah tes dan wawancara.

1. Tes

Tes serentetan pertanyaan atau latihan serta alat lain yang digunakan untuk mengukur keterampilan, pengetahuan, intelegensi, kemampuan atau bakat yang dimiliki oleh individu atau kelompok (Suharsimi Arikunto, 2010: 193).
Tes yang dilakukan dalam penelitian ini berupa tes soal uraian, yaitu soal yang jawabannya menuntut siswa untuk mengingat dan mengorganisasikan gagasan-gagasan atau hal-hal yang telah dipelajarinya dengan cara mengemukakan atau mengekspresikan gagasan tersebut dalam bentuk uraian tertulis.

Keunggulan dari soal uraian yaitu dapat mengukur siswa dalam menyajikan jawaban terurai secara bebas, mengorganisasikan pikirannya, mengemukakan pendapatnya, dan mengekspresikan gagasan-gagasan dengan menggunakan kata-kata atau kalimat siswa sendiri.

2. Wawancara

Sugiyono (2010:

"wawancara digunakan sebagai teknik pengumpulan data apabila ingin melakukan studi pendahuluan untuk menemukan permasalahan yang harus diteliti, dan juga apabila peneliti ingin mengetahui hal-hal dari responden yang lebih mendalam dan jumlah respondennya sedikit/kecil".

Emzir (2011: 60) mengemukakan kelebihan dari instrumen pengumpulan data melalui wawancara sebagai berikut.

a. Wawancara merupakan instrumen yang paling baik untuk memilih dan menilai karakteristik pribadi.

b. Wawancara mempunyai manfaat yang besar dalam mengidentifikasi dan mengatasi masalah-masalah kemanusiaan khususnya masalah efektif.

c. Wawancara mempunyai manfaat yang besar dalam konsultai.

d. Wawancara membekali peneliti dengan informasi tambahan untuk memperkuat data yang diperoleh melalui instrumen lain. 
e. Kadang-kadang peneliti menggunakan wawancara bersamasama dengan dengan observasi untuk memperkuat validitas data yang diperoleh melalui konfirmasi.

f. Wawancara merupakan satusatunya instrumen untuk pengumpulan data pada masyarakat buta huruf.

Wawancara dalam penelitian ini dilakukan secara terstruktur. Wawancara terstruktur digunakan sebagai teknik pengumpulan data, bila peneliti atau pengumpul data telah mengetahui dengan pasti tentang informasi yang akan diperoleh. Oleh karena itu dalam melakukan wawancara, pengumpul data telah menyiapkan instrumen penelitian berupa pertanyaan-pertanyaan tertulis yang alternatif jawabannya pun telah disiapkan. Dengan wawancara terstruktur ini setiap responden diberi pertanyaan yang sama dan pengumpul data mencatatnya.

Dalam melakukan wawancara, selain harus membawa instrumen sebagai pedoman untuk wawancara, maka pengumpul data juga dapat menggunakan alat bantu seperti tape recorder, gambar, brosur, dan material lain yang dapat membantu pelaksanaan menjadi lancar.

3. Dokumentasi

Dokumentasi dari katanya dokumen, yang artinya barang-barang tertulis. Di dalam melaksanakan metode dokumentasi, peneliti meyelidiki benda-benda tertulis seperti buku-buku, majalah, dokumen, peraturan-peraturan, notulen rapat, catatan harian dan sebagainya (Suharsimi Arikunto, 2010: 201).

Menurut Suharsimi Arikunto (2010: 201-202) metode dokumentasi dapat dilaksanakan dengan:

a. Pedoman dokumentasi yang memuat garis-garis besar atau kategori yang akan dicari datanya.

b. Check-list, yaitu daftar variabel yang akan dikumpulkan datanya. Dalam hal ini peneliti tinggal memberikan tanda atau tally setiap pemunculan gejala yang dimaksud.

Penelitian menggunakan metode dokumentasi ini digunakan peneliti untuk mendapatkan data berupa daftar nilai. Daftar nilai ini akan menjadi bukti bahwa peneliti benar-benar melakukan penelitian. Hal ini dikhawatirkan kalau data peneliti hilang dan data ini bisa menjadi bukti oleh peneliti.

\section{Hasil Penelitian dan Pembehasan}

Berdasarkan data hasil analisis tes maupun wawancara yang telah didapatkan, peneliti menuliskan ringkasan hasil dari analisis data tes dan hasil dari analisis data wawancara tersebut pada tabel 1. di bawah ini: 
Tabel 1. Analisis Pemahaman Hasil Tes Tulis dan Wawancara

\begin{tabular}{|c|c|c|c|c|c|c|c|c|c|c|}
\hline \multirow{2}{*}{$\begin{array}{c}\text { Sub- } \\
\text { jek }\end{array}$} & \multicolumn{2}{|c|}{$\begin{array}{c}\text { Menafsir- } \\
\text { kan }\end{array}$} & $\begin{array}{c}\text { Menco } \\
\text { ntoh- } \\
\text { kan }\end{array}$ & $\begin{array}{c}\text { Mengkla- } \\
\text { sifikasi- } \\
\text { kan }\end{array}$ & $\begin{array}{c}\text { Me- } \\
\text { rang- } \\
\text { kum }\end{array}$ & $\begin{array}{c}\text { Menyim } \\
\text {-pulkan }\end{array}$ & $\begin{array}{c}\text { Mem- } \\
\text { banding } \\
\text { kan }\end{array}$ & $\begin{array}{c}\text { Menjelas- } \\
\text { kan }\end{array}$ & $\begin{array}{c}\text { Ketera- } \\
\text { Kgan } \\
\text { Kemamp } \\
\text { uan }\end{array}$ \\
\hline$(1)$ & $(2)$ & $(3)$ & $(3)$ & $(4)$ & $(5)$ & $(6)$ & $(7)$ & $(8)$ & $(9)$ & $(10)$ \\
\hline 1 & $\begin{array}{c}\text { PA1 } \\
\text { a }\end{array}$ & - & PB1a & PC1a & PD1a & PE2a & PF1a & PG1a & - & Tinggi \\
\hline 2 & - & $\begin{array}{c}\text { PA2 } \\
\text { a }\end{array}$ & PB1a & PC1a & PD1a & PE2a & PF2a & - & $\begin{array}{c}\text { PG2 } \\
\text { a }\end{array}$ & Tinggi \\
\hline 3 & $\begin{array}{c}\text { PA1 } \\
\text { b }\end{array}$ & - & PB1b & PC1b & PD1b & PE2b & PF1b & $\begin{array}{c}\text { PG1 } \\
\text { b }\end{array}$ & - & Sedang \\
\hline 4 & - & $\begin{array}{c}\text { PA2 } \\
\text { b }\end{array}$ & PB1b & PC1b & PD1b & PE2b & PF2b & - & $\begin{array}{c}\text { PG2 } \\
\text { b }\end{array}$ & Sedang \\
\hline 5 & $\begin{array}{c}\text { PA1 } \\
\text { c }\end{array}$ & - & PB1c & PC1c & PD1c & PE2c & PF1c & PG1c & - & Rendah \\
\hline 6 & - & PA2 & PB1c & PC1c & PD1c & PE2c & PF2c & - & $\begin{array}{c}\text { PG2 } \\
\text { c }\end{array}$ & Rendah \\
\hline
\end{tabular}

\section{Keterangan:}

1. Subjek 1 dan 2 merupakan subjek dengan kategori tinggi.

2. Subjek 3 dan 4 merupakan subjek dengan kategori sedang

3. Subjek 5 dan 6 merupakan subjek dengan kategori rendah.

Dari hasil analisis tes dan wawancara pada tabel di atas, dapat diuraikan sebagai berikut:

1. Pada kolom (2) dan (3)

Secara umum, dalam tahap menafsirkan belum dapat ditunjukkan perbedaan antara ke enam mahasiswa, karena antara sesama mahasiswa yang berkategori tinggi, sedang dan rendah terdapat perbedaan kode dan pemahaman, sehingga tidak dapat diambil kesimpulan, karena belum mampu menunjukkan perbedaan antara subjek yang berkategori tinggi, sedang, dan rendah.

2. Pada kolom (4)

Secara umum, subjek dengan kategori tinggi, sedang dan rendah memenuhi proses kognitif mencontohkan. Namun terdapat perbedaan kecenderungan antara subjek kategori tinggi, sedang, dan rendah. Subjek kategori tinggi memiliki kecenderungan memberikan lebih dari satu contoh masalah trigonometri yang memenuhi kode PB1a dengan indikator baik. Hal ini menyatakan bahwa kedua subjek tersebut mempunyai pemahaman yang lebih dalam menggunakan langkahlangkah yang tepat untuk menyelesaikan masalah dengan benar. Sedangkan subjek kategori sedang memiliki kecenderungan yang berbeda pula, kedua subjek dengan kategori sedang memiliki kecenderungan memberikan satu contoh masalah trigonometri yang memenuhi kode PB1b. Hal ini menyatakan bahwa kedua subjek tersebut mempunyai pemahaman yang biasa untuk memberikan contoh pada tahap memahami masalah. Sedangkan subjek kategori rendah memiliki kecenderungan dalam memahami masalah yang kurang baik. Kedua subjek kategori rendah yang memenuhi kode PB1c cenderung kurang mampu memberikan contoh masalah trigonometri, kedua subjek ini mempunyai indikator kurang. Hal ini menyatakan bahwa kedua subjek tersebut mempunyai pemahaman yang kurang 
dalam penggunaan langkah-langkah untuk menyelesaikan masalah pada tahap merencanakan penyelesaian masalah. Sehingga terdapat perbedaan pemenuhan indikator antara subjek satu dengan subjek yang lain.

3. Pada kolom (5)

Secara umum, subjek dengan kategori tinggi, sedang dan rendah memenuhi proses kognitif Mengklasifikasikan. Namun terdapat perbedaan kecenderungan antara subjek kategori tinggi, sedang, dan rendah. Kedua subjek kategori tinggi memiliki kecenderungan memberikan lebih dari satu ciri-ciri masalah trigonometri yang memenuhi kode PC1a dengan indikator baik. Hal ini menyatakan bahwa kedua subjek tersebut mempunyai pemahaman yang lebih dalam menggunakan langkah-langkah yang tepat untuk menyelesaikan masalah dengan benar. Sedangkan subjek kategori sedang memiliki kecenderungan yang berbeda pula, kedua subjek dengan kategori sedang memiliki kecenderungan memberikan satu ciri-ciri masalah trigonometri yang memenuhi kode PC1b. Hal ini menyatakan bahwa kedua subjek tersebut mempunyai pemahaman yang biasa untuk memberikan contoh pada tahap merencanakan penyelesaian masalah. Sedangkan subjek kategori rendah memiliki kecenderungan dalam memahami masalah yang kurang baik. Kedua subjek kategori rendah yang memenuhi kode PC1c cenderung kurang mampu memberikan ciri-ciri masalah trigonometri, kedua subjek ini mempunyai indikator kurang. Hal ini menyatakan bahwa kedua subjek tersebut mempunyai pemahaman yang kurang dalam penggunaan langkah-langkah untuk menyelesaikan masalah pada tahap merencanakan penyelesaian masalah. Sehingga terdapat perbedaan pemenuhan indikator antara subjek satu dengan subjek yang lain.

4. Pada kolom (6)
Secara umum, subjek dengan kategori tinggi, sedang dan rendah memenuhi proses kognitif merangkum. Namun terdapat perbedaan kecenderungan antara subjek kategori tinggi, sedang, dan rendah. Kedua subjek kategori tinggi memiliki kecenderungan meringkas lebih dari satu masalah trigonometri yang memenuhi kode PD1a dengan indikator baik. Hal ini menyatakan bahwa kedua subjek tersebut mempunyai pemahaman yang lebih dalam menggunakan langkahlangkah yang tepat untuk menyelesaikan masalah dengan benar. Sedangkan subjek kategori sedang memiliki kecenderungan yang berbeda pula, kedua subjek dengan kategori sedang memiliki kecenderungan mampu meringkas satu masalah trigonometri yang memenuhi kode PD1b. Hal ini menyatakan bahwa kedua subjek tersebut mempunyai pemahaman yang biasa dalam menggunakan langkahlangkah yang tepat untuk menyelesaikan masalah. Sedangkan subjek kategori rendah memiliki kecenderungan dalam memahami masalah yang kurang baik. Kedua subjek kategori rendah yang memenuhi kode PD1c cenderung kurang mampu meringkas satu masalah trigonometri, kedua subjek ini mempunyai indikator kurang. Hal ini menyatakan bahwa kedua subjek tersebut mempunyai pemahaman yang kurang dalam penggunaan langkah-langkah untuk menyelesaikan masalah pada tahap merencanakan penyelesaian masalah. Sehingga terdapat perbedaan pemenuhan indikator antara subjek satu dengan subjek yang lain.

5. Pada kolom (7)

Secara umum, subjek dengan kategori tinggi, sedang dan rendah memenuhi proses kognitif menyimpulkan. Namun terdapat perbedaan kecenderungan antara subjek kategori tinggi, sedang, dan rendah. Kedua subjek kategori tinggi memiliki kecenderungan memprediksikan dengan tepat suatu masalah trigonometri yang memenuhi 
kode PE2a dengan indikator baik. Hal ini menyatakan bahwa kedua subjek tersebut mempunyai pemahaman yang lebih dalam menggunakan langkah-langkah yang tepat untuk menyelesaikan masalah dengan benar. Sedangkan subjek kategori sedang memiliki kecenderungan yang berbeda pula, kedua subjek dengan kategori sedang memiliki kecenderungan mampu memprediksikan suatu masalah trigonometri yang memenuhi kode PE2b. Hal ini menyatakan bahwa kedua subjek tersebut mempunyai pemahaman yang biasa dalam menggunakan langkahlangkah yang tepat untuk menyelesaikan masalah. Sedangkan subjek kategori rendah memiliki kecenderungan dalam memahami masalah yang kurang baik. Kedua subjek kategori rendah yang memenuhi kode PE2c cenderung kurang mampu memprediksikan suatu masalah trigonometri, kedua subjek ini mempunyai indikator kurang. Hal ini menyatakan bahwa kedua subjek tersebut mempunyai pemahaman yang kurang dalam penggunaan langkah-langkah untuk menyelesaikan masalah pada tahap memahami masalah. Sehingga terdapat perbedaan pemenuhan indikator antara subjek satu dengan subjek yang lain.

6. Pada kolom (8)

Secara umum, subjek dengan kategori tinggi, sedang dan rendah memenuhi proses kognitif membandingkan. Namun terdapat perbedaan kecenderungan antara subjek kategori tinggi, sedang dan rendah. Subjek 1 kategori tinggi memiliki kecenderungan menganalisis lebih dari satu masalah trigonometri yang memenuhi kode PF1a dengan indikator baik. Sedangkan subjek 2 memiliki kecenderungan menjodohkan lebih dari satu masalah trigonometri dalam suatu kalimat matematika yang memenuhi kode PF2a. Hal ini menyatakan bahwa kedua subjek tersebut mempunyai pemahaman yang lebih dalam menggunakan langkahlangkah yang tepat untuk menyelesaikan masalah dengan benar. Sedangkan subjek kategori sedang memiliki kecenderungan yang berbeda pula, subjek 3 memiliki kecenderungan dalam menganalisis satu masalah trigonometri yang memenuhi kode PF1b. Sedangkan subjek 4 memiliki kecenderungan menjodohkan satu masalah trigonometri dalam suatu kalimat matematika yang memenuhi kode PF2b. Hal ini menyatakan bahwa kedua subjek tersebut mempunyai pemahaman yang biasa untuk menyelesaikan masalah pada tahap merencanakan penyelesaian masalah. Sedangkan subjek kategori rendah memiliki kecenderungan dalam memahami masalah yang kurang baik. Subjek 5 yang memenuhi kode PF1c cenderung kurang mampu menganalisis masalah trigonometri, sedangkan subjek 6 yang memenuhi kode PF2c kurang mampu menjodohkan masalah trigonometri dalam suatu kalimat matematika, kedua subjek ini mempunyai indikator kurang. Hal ini menyatakan bahwa kedua subjek tersebut mempunyai pemahaman yang kurang dalam penggunaan langkah-langkah untuk menyelesaikan masalah pada tahap merencaknakan penyelesaian masalah. Sehingga terdapat perbedaan pemenuhan indikator antara subjek satu dengan subjek yang lain.

7. Pada kolom (9) dan (10)

Secara umum, dalam tahap menjelaskan belum dapat ditunjukkan perbedaan pemahaman antara ke enam mahasiswa, karena antara sesama mahasiswa yang berkategori tinggi, sedang dan rendah terdapat perbedaan kode dan pemahaman, sehingga tidak dapat diambil kesimpulan, karena belum mampu menunjukkan perbedaan antara subjek yang berkategori tinggi, sedang, dan rendah.

\section{Kesimpulan dan Saran}

Berdasarkan hasil penelitian analisis pemahaman yang telah dilakukan pada mahamahasiswa IKIP PGRI Madiun Program Studi Pendidikan Matematika semester VI kelas $\mathrm{H}$ dalam mengaplikasikan langkah- 
langkah untuk menyelesaikan masalah pada materi trigonometri berdasarkan langkah Polya dengan kategori mahasiswa tinggi, sedang, dan rendah, maka kesimpulan yang dapat diambil dari penelitian ini adalah sebagai berikut:

1. Dalam memahami masalah, mahasiswa kategori tinggi dalam memahami dan menggunakan langkah-langkah sudah cukup baik, sedangkan mahasiswa kategori sedang dan rendah cenderung memiliki pemahaman yang kurang dalam penggunaan langkah-langkah. Semua mahasiswa kategori tinggi, sedang, dan rendah pemahaman dan pemikiran kecenderungan yang kurang baik. Sedangkan semua mahasiswa kategori tinggi, sedang, dan rendah dalam menyusun langkah-langkah untuk menyelesaikan soal cenderung memiliki pemahaman yang kurang baik dalam mengaplikasikan langkah-langkah.

2. Dalam merencanakan penyelesaian masalah, mahasiswa kategori tinggi dalam mengorganisasikan langkah-langkah sesuai pengetahuan dan pengalaman dalam menyelesaikan soal memiliki pemahaman yang baik, sedangkan mahasiswa kategori sedang dan rendah cenderung memiliki pemahaman yang kurang. Semua mahasiswa kategori tinggi, sedang, dan rendah dalam melakukan pemahaman dan pemikiran dalam mengaplikasikan langkah-langkah memiliki kecenderungan yang kurang baik. Sedangkan semua mahasiswa kategori tinggi, sedang, dan rendah dalam mengaplikasikan langkah-langkah untuk menyusun langkah-langkah penyelesaian soal cenderung memiliki pemahaman yang kurang baik.

3. Dalam melaksanakan penyelesaian masalah, mahasiswa kategori tinggi dalam melakukan perhitungan dan menghitung soal matematika memiliki kecenderungan yang baik dan mampu menggunakan langkah-langkah dengan tepat, sedangkan mahasiswa kategori sedang dan rendah memiliki kecenderungan pemahaman yang kurang baik. Sedangkan semua mahasiswa kategori tinggi, sedang, dan rendah dalam mengunakan langkahlangkah untuk menyusun langkah-langkah dalam menyelesaikan soal memiliki kecenderungan yang kurang baik.

4. Dalam memeriksa kembali hasil yang diperoleh, mahasiswa kategori tinggi dalam melakukan mengorganisasikan pengetahuan dan pengalaman penggunaan langkah-langkah dalam menyelesaikan soal memiliki kecenderungan pemahaman yang baik, sedangkan mahasiswa kategori sedang dan rendah cenderung memiliki pemahaman yang kurang. Semua mahasiswa kategori tinggi, sedang, dan rendah dalam melakukan kesalahan tindakan dan pemikiran memiliki kecenderungan yang kurang baik. Mahasiswa kategori tinggi dalam melakukan perhitungan dan menghitung soal matematika memiliki kecenderungan yang baik dalam penggunaan langkahlangkah, sedangkan mahasiswa kategori sedang dan rendah memiliki kecenderungan pemahaman yang kurang baik. Sedangkan semua mahasiswa kategori tinggi, sedang, dan rendah dalam mengaplikasikan langkah-langkah untuk menyusun langkah-langkah dalam menyelesaikan soal memiliki kecenderungan yang kurang baik.

Berdasarkan kesimpulan di atas, maka beberapa hal yang perlu penulis sarankan, antara lain sebagai berikut:

\section{Bagi Mahasiswa:}

a. Untuk mencapai hasil yang baik diperlukan usaha yang sungguhsungguh, maka sebaiknya dalam mengerjakan suatu soal tidak hanya terpacu dengan cepatnya dalam mengerjakan soal tersebut, namun yang utama adalah ketepatan dalam proses dan hasil pengerjaan soal itu.

b. Membaca adalah kunci utama belajar, begitu pula dengan pembelajaran pemecahan masalah dengan menggunakan langkah Polya dalam memecahkan masalah soal 
trigonometri, pemahaman dalam isi soal sangatlah penting karena akan berpengaruh pada hasil akhir.

2. Bagi peneliti lain yang tertarik melakukan penelitian yang sejenis tentang profil pemahaman mahasiswa dalam mengaplikasikan langkah-langkah, hendaknya dilakukan penelitian lebih lanjut tentang jenis-jenis pemahaman untuk mengetahui pemahaman mahasiswa dalam mengerjakan soal matematika dan melakukan observasi lebih lanjut untuk mendapatkan mahasiswa yang pantas dijadikan subjek dalam penelitian sesuai dengan prestasi mahasiswa.

3. Kelemahan dan keterbatasan

Dalam penelitian ini peneliti belum mampu menunjukkan secara umum kecenderungan pemahaman antara mahasiswa yang berkategori tinggi, sedang dan rendah. Hanya mampu menunjukan sampai tingkat kategori, karena terdapat tahap dalam indikator yang tidak dipenuhi oleh subjek.

Dalam memahami masalah, merencanakan penyelesaian masalah, melaksanakan penyelesaian masalah, dan memeriksa kembali hasil yang diperoleh dalam mengorganisasikan pengetahuan dan pengalaman untuk menyelesaikan soal, karena adanya keterbatasan pemenuhan indikator antara subjek satu dengan subjek lainnya.

\section{DAFTAR PUSTAKA}

Anderson dan Krathwohl. 2010. Kerangka Landasan Untuk Pembelajaran, Pengajaran, dan Asesmen. Terjemahan oleh Agung Prihantoro. Yogyakarta: Pustaka Pelajar

Anwar Sutoyo. 2012. Pemahaman Individu. Yogyakarta: Pustaka Pelajar

Emzir. 2011. Metodologi Penelitian Kualitatif Analisis Data. Jakarta: PT. Raja Grafindo Persada
Erman Suherman, dkk. 2003. Strategi Pembelajaran Matematika Kontemporer. Bandung: Universitas Pendidikan Indonesia

Herman Hudojo. 2005. Pengembangan Kurikulum dan Pembelajaran Matematika. Malang: UM Press

Muhammad. 2011. Pengertian Pemahaman (online). (http://id.shvoong.com/socialsciences/education/2203596pengertian-pemahaman.html, Diunduh 28 Pebruari 2013)

Mustaqim dan Abdul Wahab. 2003. Psikologi Pendidikan. Jakarta: PT. Rineka Cipta

Nana Syaodih Sukmadinata. 2009. Landasan Psikologi Proses Pendidikan. Bandung: PT. Remaja Rosdakarya

Sri Kurnianingsih, dkk. 2006. Matematika SMA. Jakarta: Gelora Aksara Pratama

Sugiyono. 2010. Metode Penelitian Pendidikan Pendekatan Kuantitatif, Kualitatif, dan $R \& D$. Bandung: Alfabeta

Sugiyono. 2012. Memahami Penelitian Kualitatif. Bandung: Alfabeta

Suharsimi Arikunto. 2010. Prosedur Penelitian Suatu Pendekatan Praktik. Jakarta: PT. Rineka Cipta

Sukirman. 2003. Matematika. Jakarta: Universitas Terbuka

Sutopo. 2002. Metodologi Penelitian Kualitatif. Surakarta: UNS Press 